\title{
Pola Menonton Televisi dan Pengaruhnya Terhadap Anak
}

\section{Terapul Tarigan, Nancy Ervani, Syamsidah Lubis}

Subbagian Tumbuh kembang Pediatri Sosial, Bagian Ilmu Kesehatan Anak Fakultas Kedokteran Universitas Sumatera Utara/ RS. Dr. Pirngadi Medan

Latar belakang. Beberapa penelitian menyatakan bahwa menonton televisi telah menciptakan berbagai penyakit sosial termasuk membuat pelajar menjadi pasif yang sulit untuk berkonsentrasi dalam belajar yang akan menyebabkan menurunnya nilai ujian serta menyebabkan aktifitas yang kurang yang dapat menyebabkan obesitas. ${ }^{1,3}$

Tujuan Penelitian. Penelitian ini bertujuan untuk mengetahui pola menonton pada anak dan pengaruhnya terhadap pendidikan serta pola makan.

Metode. Penelitian deskriptif analitik yang bersifat cross-sectional. Penilaian dilakukan dengan pengisian kuesioner pada 100 ibu, yang dilakukan di TK Ahmad Yani, Binjai. Sumatera Utara pada bulan Maret 2006.

Hasil. Umur ibu yang ikut dalam penelitian terbanyak usia 31-40 tahun (65\%). Pendidikan terbanyak dari para ibu responden adalah tamatan SMU(49\%), rata-rata ibu tidak bekerja (59\%). Usia anak pertama kali menonton televisi 38 (38\%) terbanyak pada usia 3-5 tahun, lama menonton televisi perhari 1-2 jam sebanyak $56(56 \%)$ dan acara yang paling disenangi oleh anak adalah kartun 77 (77\%). Namun tidak memperlihatkan hubungan yang signifikan antara lama menonton televisi, usia pertama kali anak menonton, acara yang disenangi terhadap pendidikan, dan pola makan anak.

Kesimpulan. Menonton televisi mempunyai pengaruh terhadap belajar anak dan pola makan dari anak tetapi tidak bermakna secara statistik. Diperlukan penelitian lanjutan untuk menilai pengaruh televisi terhadap perilaku anak pada usia berikutnya (Sari Pediatri 2007; 9(10):44-47).

Kata kunci: menonton televisi, belajar, pola makan

Alamat korespondensi:

Dr. Terapul Tarigan, Sp.A.

Subbagian Tumbuh kembang Pediatri Sosial. Bagian Ilmu Kesehatan Anak FK-USU/ RS. Dr. Pirngadi Medan.

Telepon: 061 4554891. E-mail: Terapul Tarigan Yahoo@.co.id
7 elevisi merupakan media yang tidak asing lagi, hampir semua rumah tangga mene ngah keatas di Indonesia memiliki pesawat televisi. Dalam satu dekade ini berbagai saluran televisi tumbuh menawarkan berbagai acara yang mampu menghibur masyarakat walaupun tidak semua 
program yang ditawarkan bersifat mendidik. ${ }^{1}$ American Academy of Pediatrics (AAP) telah melaporkan dampak negatif dan positif dari media massa terhadap anak dan dewasa. ${ }^{2}$ Manfaat yang diperoleh dari program televisi adalah yang bersifat pendidikan bahkan sampai pada kreatifitas dan pengetahuan menggunakan komputer. Efek negatif dari media massa adalah banyaknya menghabiskan waktu dengan menonton televisi, pengaruh dari kekerasan di media terhadap tingkah laku anak yang agresif, terhadap pendidikan dan obesitas. ${ }^{2-6}$

Berdasarkan survei yang dilakukan oleh Annenberg Public Policy Centre terhadap rumah tangga di Amerika Serikat, membuktikan bahwa rata-rata anak di AS menghabiskan waktu mereka sebanyak 25 jam per minggu di depan layar kaca. Hal ini melampaui standar yang diajukan oleh AAP. ${ }^{13,4,7}$

Pada tahun 1990 AAP menganjurkan agar anak tidak menonton televisi lebih dari 2 jam per hari dan acara yang ditonton haruslah yang berkualitas. Namun bulan lalu AAP mengeluarkan peraturan yang lebih ketat lagi, anak-anak di bawah usia 2 tahun sebaiknya tidak menonton televisi sama sekali dan anak-anak di atas usia tersebut sebaiknya tidak mempunyai pesawat televisi sendiri di kamar mereka. ${ }^{1,8-12}$ Penelitian sebelumnya membuktikan bahwa televisi mempunyai pengaruh yang buruk terhadap perkembangan fisik dan mental anak. Bukan berarti semua acara televisi itu buruk. Menonton televisi terlalu banyak secara terus menerus dan tidak memilih acara yang baik, efeknya akan sangat buruk bagi perkembangan anak. ${ }^{1,13,14}$ Pada artikel ini, kami menilai mengenai pola menonton televisi pada anak dan pengaruh terhadap pendidikan dan pola makan anak.

\section{Metode}

Penelitian deskriptif analitik dengan desain crosssectional. Data diperoleh dengan pengisian kuesioner pada $100 \mathrm{ibu}$, yang dilakukan di TK Ahmad Yani, Binjai. Sumatera Utara pada bulan Mei 2006. Pengolahan data menggunakan program SPSS versi 12.0. Analisis univariate menggunakan chi-square.

\section{Hasil}

Dari 100 anak yang ikut dalam penelitian, 53 anak laki-laki dan 47 anak perempuan dengan usia anak rata-rata 3-6 tahun.
Tabel 1. Karakteristik demografi dari ibu responden

\begin{tabular}{lc}
\hline Variabel & $\mathrm{n}(\%)$ \\
\hline Usia ibu (tahun) & \\
$21-30$ & $27(27)$ \\
$31-40$ & $65(65)$ \\
$41-50$ & $8(8)$ \\
Pendidikan ibu & \\
SD & $3(3)$ \\
SMP & $12(12)$ \\
SMU & $49(49)$ \\
Perguruan tingi & $36(36)$ \\
Pekerjaan ibu & \\
Bekerja & $41(41)$ \\
Tidak bekerja & $59(59)$ \\
\hline
\end{tabular}

Tabel 2. Karakteristik \& pola menonton televisi pada anak

\begin{tabular}{lc}
\hline Variabel & $\mathrm{n}(\%)$ \\
\hline Jenis kelamin & \\
$\quad$ Laki-laki & $53(53)$ \\
$\quad$ Perempuan & $47(47)$ \\
Usia pertama kali menonton televisi (tahun) & \\
$\quad<3$ & $24(24)$ \\
$3-5$ & $38(38)$ \\
6-8 & $27(27)$ \\
$9-11$ & $11(11)$ \\
Acara televisi yang disenangi anak & \\
Kartun & $77(77)$ \\
Musik & $7(7)$ \\
Sinetron & $1(1)$ \\
Flora fauna & $5(5)$ \\
Kuis & $2(2)$ \\
Pendidikan & $1(1)$ \\
Kartun \& musik & $2(2)$ \\
Kartun \& flora fauna & $(4)$ \\
Semua & $1(1)$ \\
\hline
\end{tabular}

Tabel 1 menunjukkan bahwa kisaran umur ibu yang ikut dalam penelitian terbanyak usia 31-40 tahun (65\%). Pendidikan terbanyak dari para ibu responden adalah tamatan SMU(49\%), dan rata-rata ibu tidak bekerja (59\%).

Tabel 2 memperlihatkan karakteristik dari anak yaitu berdasarkan jenis kelamin yang terbanyak adalah laki-laki 53(53\%). Berdasarkan usia pertama kali menonton televisi terbanyak pada usia 3-5 tahun 38 (38\%), lama menonton televisi/ hari adalah 1-2 jam sebanyak 56 (56\%) dan acara yang paling disenangi oleh anak adalah kartun 77 (77\%). 


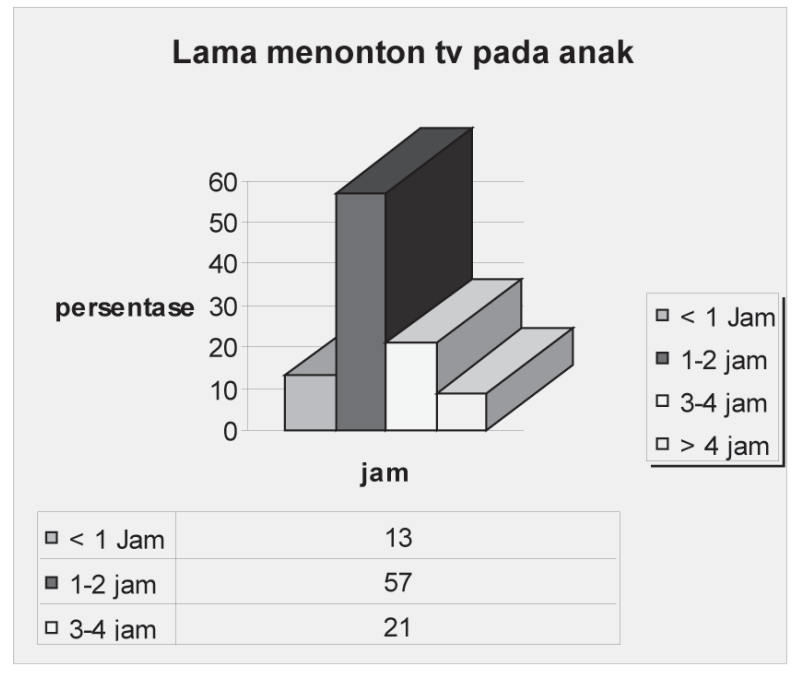

Gambar 1. menunjukkan bahwa rata-rata anak menonton televisi 1-2 jam perhari yaitu 57 (57\%)

Tabel 3. Hubungan antara pekerjaan ibu dan pendidikan ibu dengan lama anak menonton televisi

\begin{tabular}{lccc}
\hline Variabel & $\mathrm{x}^{2}$ & $\mathrm{df}$ & $\mathrm{p}$ value \\
\hline Pekerjaan ibu & 2,173 & 3 & 0,537 \\
Pendidikan ibu & 10,751 & 9 & 0,293 \\
\hline
\end{tabular}

Tabel 4. Pengaruh lama menonton dan, usia anak pertama kali menonton televisi terhadap belajar anak \& pola makan anak

\begin{tabular}{lccc}
\hline Variabel & $\mathrm{x}^{2}$ & $\mathrm{df}$ & $\mathrm{p}$ \\
\hline Lama menonton TV & 1,964 & 3 & 0,580 \\
Usia pertama kali menonton TV & 0,504 & 3 & 0,918 \\
Acara yang disenangi &, 141 & 6 & 0,791 \\
\hline
\end{tabular}

Tabel 3 memperlihatkan tidak ada hubungan signifikan antara pekerjaan ataupun pendidikan ibu dengan lamanya anak menonton televisi.

Tabel 4 memperlihatkan tidak ada hubungan signifikan antara lama menonton televisi, usia pertama kali anak menonton dan acara yang disenangi terhadap pendidikan dan pola makan anak.

Tabel 5 menunjukkan hubungan signifikan antara acara yang disenangi anak dengan reaksi anak setelah menonton televisi $(\mathrm{p}<0,05)$.

Gambar 2 dan 3 memperlihatkan bahwa menonton televisi mempunyai pengaruh pada anak sebesar 32(32\%) dengan pengaruh pada belajar $17(17 \%)$ dan pola makan $15(15 \%)$.
Tabel 5. Reaksi anak terhadap acara televisi yang disenangi

\begin{tabular}{lccc}
\hline Variabel & $\mathrm{x}^{2}$ & $\mathrm{df}$ & $\mathrm{p}$ \\
\hline Acara yang disenangi & 35,189 & 18 & 0,009 \\
\hline
\end{tabular}

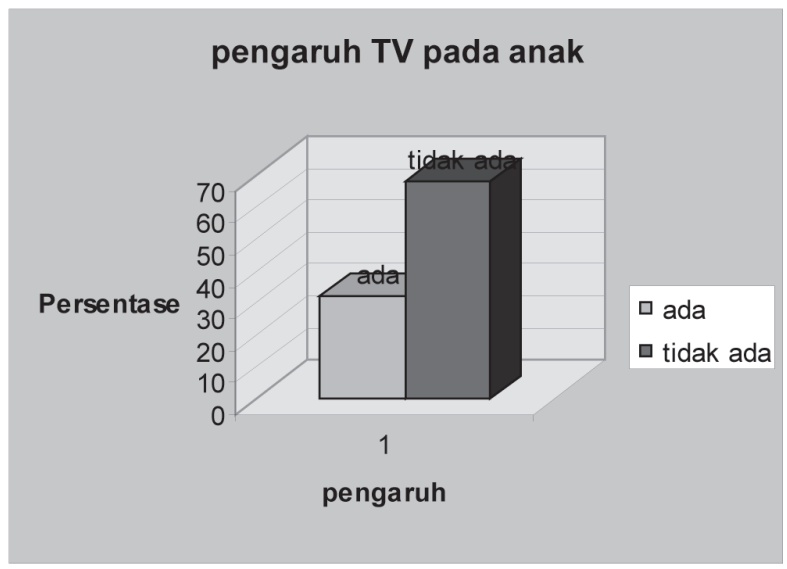

Gambar 2. Pengaruh TV terhadap anak

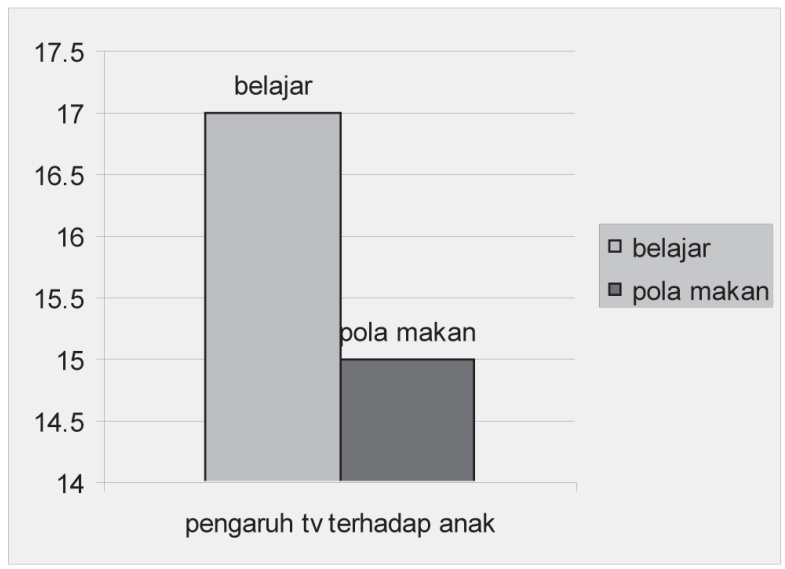

Gambar 3. Pengaruh menonton televisi terhadap pola makan dan belajar anak

\section{Diskusi}

Menonton televisi telah menciptakan berbagai penyakit sosial termasuk menciptakan pelajar pasif yang sulit untuk berkonsentrasi dalam belajar yang akan menyebabkan menurunnya nilai ujian, aktifitas yang kurang yang dapat menyebabkan obesitas. ${ }^{1,3}$ Berdasarkan penelitian Owens J dkk ${ }^{4}$, menyebutkan bahwa kebiasaan menonton televisi berhubungan secara signifikan dengan gangguan tidur akibat meningkatnya 
waktu menonton televisi pada malam hari terutama anak yang mempunyai televisi dikamar tidur. Hal ini sesuai dengan penelitian sebelumnya yang membuktikan bahwa anak-anak yang banyak menghabiskan waktu mereka di depan layar kaca memiliki prestasi yang buruk di sekolah. Anak yang menonton televisi terus menerus akan mempunyai waktu yang lebih sedikit untuk beraktivitas dengan orang lain dan yang lebih penting habis waktu mereka untuk membuat pekerjaan rumah (PR) atau tugas lain yang diberikan guru. Menonton televisi pada malam hari membuat mereka mengantuk pada siang harinya yang mengakibatkan sulit konsentrasi disekolah. Hal ini yang menyebabkan prestasi anak disekolah menurun. ${ }^{2-6}$

Penelitian ini membuktikan bahwa menonton televisi mempunyai pengaruh terhadap belajar anak tetapi tidak bermakna secara statistik. Diantara 100 anak yang mempunyai pengaruh terhadap belajar 17 anak (17\%).

Anak yang lebih banyak duduk didepan layar TV akan menyebabkan aktifitas anak sedikit sehingga hanya sedikit kalori yang terbuang akibatnya badan mereka menjadi gemuk. Berdasarkan penelitian Faith MS, dkk ${ }^{5}$ mendapatkan bahwa anak obesitas yang diberi intervensi berupa pengurangan waktu menonton televisi dapat menurunkan berat badan anak.

Dari penelitian ini menunjukkan bahwa ada pengaruh dari menonton televisi dengan pola makan anak dan kebiasaan makan makanan kecil di depan televisi. Namun pengaruh ini tidak bermakna. Diperlukan jumlah subjek yang lebih besar. Berdasarkan penelitian Christakis $\mathrm{DA}, \mathrm{dkk}^{8} 10 \%$ anak yang menonton televisi setiap hari mulai usia 1-3 tahun berhubungan dengan masalah gangguan perilaku pada anak usia 7 tahun. Hal ini bertentangan dengan penelitian Steven $\mathrm{T}$, dkk ${ }^{14}$ yang membuktikan tidak berhubungan secara bermakna antara menonton televisi dengan perilaku anak yaitu ADHD. Dalam penelitian ini tidak meneliti mengenai gangguan perilaku pada anak akibat dari menonton televisi. Diperlukan penelitian lanjutan untuk mengetahui hubungan tersebut.

\section{Kesimpulan}

Menonton televisi mempunyai pengaruh terhadap belajar anak dan pola makan dari anak, namun diperlukan jumlah subjek yang lebih besar untuk membuktikannya. Diperlukan penelitian lanjutan untuk menilai pengaruh televisi terhadap perilaku anak pada usia berikutnya.

\section{Daftar Pustaka}

1. Bahaya menonton televisi terlalu lama bagi anak. Diunduh dari URL: http//www.Almira-online. port5.com.

2. Committee on public Education. Media education, J. Pediatrics 1999; 104:342-3.

3. Vandewater EA, Bickham DS, Lee JH. Time well spent? Relating television use to Children's free time activities. J Pediatrics 2006; 117:e181-91.

4. Owens J, Maxim R. Television -viewing habits and sleep disturbance in school children. J Pediatrics 1999; 104: 1-8.

5. Faith MS, berman N. Effects of contingent television on physical activity and television viewing in obese children. J Pediatrics 2001; 107:1043-8.

6. Gidwani PP, Sobol A. Television viewing and initiation of smoking Among Youth. J Pediatrics 2002 ; 110:505-8.

7. Lumeng JC, Gannon K. Association between clinically meaningful behavior problems and overweight in children. J Pediatrics 2003; 112:1138-44.

8. Christakis DA, Zimmerman FJ. Early television exposure and subsequent attentional problems in children. J Pediatrics 2004; 113:708-13.

9. Cheng TL, Brenner RA. Children's violent television viewing: are parents monitoring ? J Pediatrics 2004; 114: 94-9.

10. Gentile DA, Oberg C. Well-child visit in the video age: pediatricians and the American Academy of Pediatrics Guidelines for children's media use. J Pediatrics 2004; 114:1235-41.

11. Purugganan $\mathrm{OH}$, Ruth EK. Exposure to violence among urban school-aged children: is it only on television? J Pediatrics 2000; 106:949-53.

12. Coon KA, Goldberg J. Relationships between use of television during meals and children's food consumption patterns. J Pediatrics 2001; 107:1-7.

13. Bar ME. The effects of television on child health: implication and Recommendations. J Arch Dis Child 2000; 83: 289-292.

14. Steven T, Mulsow M. There is no meaningful relationship between television exposure and symptoms of attention- deficit / hyperactivity disorder. J Pediatrics 2006; 117: 665-71. 